\title{
The effect of ethanolic extract of Brazilian green propolis and artepillin C on aFGF-1, Eselectin, and CD40L secreted by human gingival fibroblasts
}

\author{
MAŁGORZATA KŁÓSEK, ŁUKASZ SĘDEK, HANNA LEWANDOWSKA, ZENON P. CZUBA \\ Department of Microbiology and Immunology, Faculty of Medical Sciences in Zabrze, Medical University of Silesia in Katowice, \\ Zabrze, Poland
}

\begin{abstract}
Introduction: Periodontal diseases are among the most common diseases of the oral cavity in the worldwide population. The prevention of gingivitis and periodontitis is based on the removal of bacterial plaque from the teeth with use of toothpaste containing active substances. Noteworthy is the ethanolic extract of Brazilian green propolis (EEP-B), which, due to the high content of artepillin $C$, has anti-inflammatory, antibacterial, or immunostimulatory effects. Little is known about interactions between EEP-B and gingival fibroblasts within the oral cavity. The purpose of the article is to determine the role of acidic fibroblast growth factor ( $a F G F-1)$, E-selectin, and ligand of CD4O(CD4OL) secreted by human gingival fibroblasts $(H G F-1)$ in the gingiva.

Material and methods: We performed our experiments on gingival fibroblasts ( $H G F-1)$, which are an ideal in vitro model for studying the processes taking place within the gingiva. We incubated cells with EEP-B or artepillin $C$ at the concentrations of $1 \mu \mathrm{g} / \mathrm{ml}$ and $10 \mu \mathrm{g} / \mathrm{ml}$. The aFGF-1, E-selectin, and CD4OL were detected using the Bio-Plex Magnetic Luminex Assay and the Bio-Plex 200 System.

Results: Ethanolic extract of Brazilian green propolis and artepillin $C$ increased the levels of aFGF-1 secreted by HGF-1. Moreover, EEP-B decreased the levels of E-selectin in both tested concentrations, which was not proved for artepillin $C$. No changes in the concentration of CD4OL released by HGF-1 were observed.

Conclusions: The obtained results may suggest that EEP-B, due to the mixture of various compounds including flavonoids, accelerates the wound healing effects and has anti-inflammatory activity.
\end{abstract}

Key words: acidic FGF-1, artepillin C, CD4OL, E-selectin, human gingival fibroblasts, propolis.

(Cent Eur J Immunol 2021; 46 (4): 438-445)

\section{Introduction}

Periodontal diseases are highly prevalent in the worldwide population. Gingivitis is a chronic inflammatory disorder caused by bacterial biofilm in the dental plaque which may progress to periodontitis $[1,2]$. During biofilm maturation, pathogenic bacteria produce soluble compounds that stimulate host cells to produce mediators associated with the inflammatory process. The secretion of proinflammatory cytokines activates neutrophils, lymphocytes, and monocytes. High levels of interleukin $1 \beta$ (IL-1 $\beta$ ), tumor necrosis factor $\alpha$ (TNF- $\alpha$ ), and prostaglandin E2 (PGE2) correlate with the periodontal damage. The role of molecules and detailed pathways in the development of periodontal diseases is still unclear. Human gingival fibroblasts (HGFs) are the most abundant cell types in periodontal connective tissues [3] and they provide an ideal model to study processes taking place within the gingiva.

Fibroblast growth factors (FGFs) belong to a large family consisting of 22 polypeptides. These proteins bind to transmembrane receptors FGFR1-4 with tyrosine kinase activity [4]identified on the basis of amino acid sequence homologies. The FGF family has distinguished itself from other growth factor families by virtue of the pleiotropic actions of its members. This chapter discusses the structural and functional diversity in the FGF receptor multigene family. The effects of FGFs are known to be mediated by high-affinity receptor tyrosine kinases. The structurally diverse receptor molecules are also functionally different.

Correspondence: Małgorzata Kłósek, Department of Microbiology and Immunology, Faculty of Medical Sciences in Zabrze, Medical University of Silesia in Katowice, 19 Jordana St., 41-808 Zabrze, Poland, phone/fax: +48 322 722 554, e-mail: mklosek@ sum.edu.pl Submitted: 17.06.2021; Accepted: 4.10.2021 
The characterization of structural and functional diversity within the FGF receptor shows the differences in the mechanisms of action among members of the FGF family. The first members of the FGF family to be purified and characterized were acidic FGF (aFGF. FGFs and their soluble form mediate proliferation, migration, wound healing, angiogenesis, or metabolism [5, 6]. Acidic FGF (aFGF, FGF-1, heparin-binding growth factor 1) is one of the best studied members of the FGF family. It was originally identified as a mitogen for endothelial cells, but it is also mitogenic for all other types including osteoblasts, chondrocytes, and fibroblasts and a potent angiogenic factor. FGFR4 is a highly specific receptor for aFGF.

E-selectin (endothelial leukocyte adhesion molecule-1, ELAM-1, CD62E) is an adhesion molecule synthesized by endothelial cells. The expression of E-selectin is stimulated by IL- $1 \beta$, IL- 6 , TNF- $\alpha$, or bacterial lipopolysaccharide (LPS) in the inflammatory response [7]. The receptors for ELAM-1 are E-selectin ligand-1 (ESL-1), sialyl Lewis $\mathrm{x}$ $\left(\mathrm{SLE}^{\mathrm{x}}\right.$, and sialyl Lewis a (SLEa). These receptors occur on the surface of leukocytes and tumor cells [8]. During inflammation or cancer metastasis E-selectin interacts with its ligand and leads to the rolling of leukocytes on endothelial cells. Selectins are usually bound with cytoplasmic membranes of cells, but they can also be released by enzymatic cleavage into the circulation. The soluble E-selectin (sE-selectin) level correlates with its expression on the surface of endothelial cells, but little is known about its role [9]. Some studies have shown that it may act as a chemotactic signal triggering the migration of neutrophils [10]. High levels of sE-selectin have been reported in patients with inflammatory diseases $[11,12]$.

The ligand of CD40 (CD40L, CD154) is a member of the TNF superfamily. It is a costimulatory molecule on the surface of activated T lymphocytes. CD40L binds to its receptor, a CD40 molecule, which is present on B lymphocytes. It activates B cells and allows for switching of immunoglobulin classes. CD40L deficiency or defect is a cause of hyper-IgM syndrome. It has been reported that CD40L is expressed on activated B cells, dendritic cells, platelets, basophils, and eosinophils [13, 14]. CD40L on $\mathrm{T}$ lymphocytes binds CD40 on monocytes and dendritic cells, which results in secretion of cytokines such as IL-1 $\beta$, IL-6, IL-8, IL-10, IL-12, and TNF- $\alpha$ [15]. CD40L exists in two forms: membrane bound and soluble (sCD40L). The level of sCD40L in gingival crevicular fluid (GCF) is significantly higher in patients with periodontitis compared to healthy patients [16].

Propolis, also called "bee glue", is a natural substance collected by honey bees (Apis mellifera). It is a resinous secretion of tree buds and a mixture of wax, pollen, essential oils, and a small amount of glandular secretion of bees. Propolis is used by Apis mellifera as a building and insulation material $[17,18]$. Propolis possesses anti-inflammatory, antioxidant, antibacterial, anticancer, and

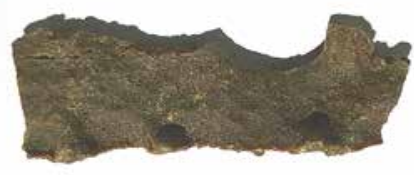

Fig. 1. Brazilian green propolis

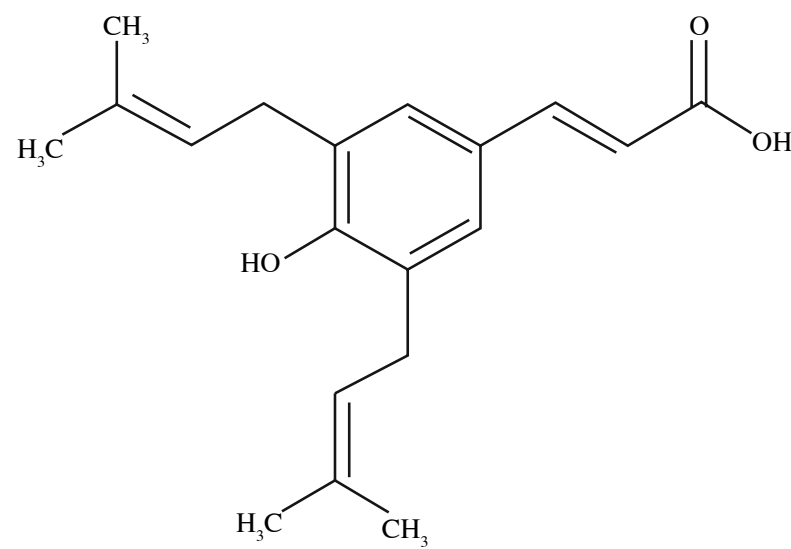

Fig. 2. Chemical structure of artepillin $\mathrm{C}$

immunomodulatory properties [19-21]. The composition of bee glue depends on the place of collection. Brazilian green propolis is collected by Africanized honeybees (Apis mellifera) mainly from Baccharis dracunculifolia DC (Asteraceae). This plant is an important source of propolis in Minas Gerais, Carvalhopolis in Brazil [22]. A photograph of Brazilian green propolis is shown in Figure 1.

The biological activities of Brazilian green propolis result from the high levels of prenylated $p$-coumaric acids, mainly artepillin C (3,5-diprenyl-p-coumaric acid) [23]. The structure of artepillin $\mathrm{C}$ is shown in Figure 2.

We investigated for the first time the effect of ethanolic extract of Brazilian green propolis (EEP-B) on selected molecules aFGF-1, E-selectin, and SCD40L secreted by human gingival fibroblasts in vitro. We compared the obtained results of EEP-B to its main ingredient, artepillin C.

\section{Material and methods}

\section{Ethanolic extract of Brazilian green propolis}

The raw Brazilian green propolis was collected manually from beehives located in the state of Minas Gerais in southeastern Brazil. The sample of propolis was kept desiccated prior to processing. The sample of propolis was extracted in $95 \% \mathrm{v} / \mathrm{v}$ ethyl alcohol for 4 days at $37^{\circ} \mathrm{C}$. Then the EEP-B was filtered through Whatman filter paper and evaporated at $60^{\circ} \mathrm{C}$. The EEP-B was dissolved in DMSO obtaining the final concentration of $20 \mathrm{mg} / \mathrm{ml}$. In the cul- 
ture medium, the final concentration of DMSO was $0.1 \%$ $(\mathrm{v} / \mathrm{v})$. EEP-B activity at the concentrations of $1 \mu \mathrm{g} / \mathrm{ml}$ and $10 \mu \mathrm{g} / \mathrm{ml}$ was evaluated after 24-hour incubation with human gingival fibroblasts (HGF-1) cells.

\section{Artepillin C}

Artepillin C (3,5-diprenyl-4-hydroxycinnamic acid) was obtained from Wako Pure Chemicals (Osaka, Japan) as a natural component isolated from Brazilian green propolis. Artepillin $\mathrm{C}$ was dissolved in dimethyl sulfoxide (DMSO) to obtain the concentrations of $1 \mu \mathrm{M}(0.3 \mu \mathrm{g} / \mathrm{ml})$ and $10 \mu \mathrm{M}(3 \mu \mathrm{g} / \mathrm{ml})$.

\section{Cell culture}

The human gingival fibroblasts cell line was obtained from the American Type Culture Collection (ATCC, Manassas, VA, USA). The cells were grown in high glucose Dulbecco's Modified Eagle Medium (DMEM), supplemented with $10 \%$ heat-inactivated fetal bovine serum (FBS; Sigma Aldrich), $100 \mathrm{U} / \mathrm{ml}$ penicillin, $0.1 \mathrm{mg} / \mathrm{ml}$ streptomycin and $8 \mathrm{mM}$ glutamine in a humidified atmosphere with $5 \% \mathrm{CO}_{2}$ at $37^{\circ} \mathrm{C}$. The cells were detached with trypsin-EDTA $\left(0.05 \%\right.$; Sigma-Aldrich) for $3 \mathrm{~min}$ at $37^{\circ} \mathrm{C}$.

\section{Cell viability - staining with trypan blue}

After 24 hours incubation of HGF-1 cells with tested compounds, the cell viability was assessed using a $0.25 \%$ trypan blue solution staining method. Trypan blue stains apoptotic and necrotic cells.

\section{Cell viability - MTT cytotoxicity assay}

The cytotoxicity was measured by the 3-(4,5-dimethylthiazol-2-yl)-2,5 diphenyltetrazolium (MTT) assay as previously described [24, 25]. This test is based on conversion of the tetrazolium salt MTT into a blue formazan dye by viable cells. HGF- 1 cells $\left(15 \times 10^{4} / \mathrm{ml}\right)$ were seeded into each well of a 96 -well plate $48 \mathrm{~h}$ before the experiments. The cells were treated for $24 \mathrm{~h}$ with EEP-B at the concentrations of $1 \mu \mathrm{g} / \mathrm{ml}, 10 \mu \mathrm{g} / \mathrm{ml}$ and $20 \mu \mathrm{g} / \mathrm{ml}$ and artepillin $\mathrm{C}$ at the concentrations of $1 \mu \mathrm{M}, 10 \mu \mathrm{M}$ and $20 \mu \mathrm{M}$ (dissolved in DMSO). After this time, the medium was removed, and $180 \mu \mathrm{l}$ of culture medium and $20 \mu \mathrm{l}$ of MTT solutions $(5 \mathrm{mg} / \mathrm{ml})$ were added to each well for 4 hours. The resulting formazan crystals were dissolved in 100\% DMSO. The reagents were purchased from Sigma Chemical Company (St. Louis, MO, USA). The controls included native cells and medium alone. The spectrophotometric absorbance of each well was measured using a microplate reader (Eon Microplate Spectrophotometer, BioTek, Winooski, VT, USA) at $550 \mathrm{~nm}$ wavelength. The cytotoxicity as the percentage of cell death was calculated using the formula: percent cytotoxicity (cell death) $=[1-($ absorbance of experimental wells/absorbance of control wells) $] \times 100 \%$.

\section{Quantification of acidic FGF-1, E-selectin, and soluble CD40L concentrations}

The concentrations of aFGF-1, E-selectin, and SCD40L released from human gingival fibroblast supernatants of cell culture were determined $24 \mathrm{~h}$ after the treatment with ethanolic extract of Brazilian green propolis and artepillin C. The measurements were performed using the BioPlex Magnetic Luminex Assay (R and D Systems, Canada, USA) and the Bio-Plex Suspension Array System (BIO-RAD Laboratories, Inc.). The technique uses color-coded (shades of red) sets of magnetic beads coated with antibodies specific for the analytes. Bead sets added to supernatants of cell cultures and standards combine with specific analytes. Bead-linked analytes are detected by adding a cocktail of biotinylated antibodies, which can then react with the streptavidin phycoerythrin conjugate. An ELx 50 magnetic washer (BioTek, USA) was used to rinse the ferromagnetic beads after each incubation period. The quantification was carried out using the Bio-Rad System 200 instrument. The instrument's operation is based on the technique used in flow cytometry using two lasers, one to recognize the color of the beads (assigned to a specific analyte) and the other to excite phycoerythrin to determine the fluorescence (measurement proportional to the amount of analyte bound). The analyte concentrations were read from the curves taking into account the appropriate standards, using the instrument control software and analysis of the results. The sensitivity of this technique is $\leq 1 \mathrm{pg} / \mathrm{ml}$ and the detection range is $\leq 1 \%$ cross-reactivity. For statistical analysis four repeats were performed in two independent experiments with $n=8$ for quantification of the acidic FGF-1, E-selectin, and soluble CD40L concentrations.

\section{Statistical analysis}

The results are expressed as the means $( \pm \mathrm{SD})$ from 8 measurements obtained from two independent experiments. The distribution of the data was verified for normality with the Shapiro-Wilk test. Statistical significance was evaluated using Student's- $t$ test. $p<0.05$ was considered significant.

\section{Results}

The concentrations of the tested substances aFGF-1, E-selectin, and CD40L secreted by HGF-1 cells presented as mean and standard deviation are shown in Figure 3I. The acidic FGF-1 significantly increased after the incubation of HGF-1 cells with $1 \mu \mathrm{g} / \mathrm{ml}$ EEP-B and $1 \mu \mathrm{M}$ artepillin $\mathrm{C}$, from $4.23 \mathrm{pg} / \mathrm{ml}$ in the control to $4.97 \mathrm{pg} / \mathrm{ml}$ and $8.40 \mathrm{pg} / \mathrm{ml}$ respectively (Fig. 3IIA). Higher concentrations $(10 \mu \mathrm{g} / \mathrm{ml}$ and $10 \mu \mathrm{M})$ did not increase the secretion of the tested substances. The EEP-B in $1 \mu \mathrm{g} / \mathrm{ml}$ and $10 \mu \mathrm{g} / \mathrm{ml}$ decreased the concentration of E-selectin from $4.36 \mathrm{pg} / \mathrm{ml}$ to $1.14 \mathrm{pg} / \mathrm{ml}$ and $1.42 \mathrm{pg} / \mathrm{ml}$ (Fig. 2IIB), which was not 
I.

\begin{tabular}{ccccc}
\hline & \multicolumn{2}{c}{ EEP-B } & \multicolumn{2}{c}{ Artepillin C } \\
& $1 \mu \mathrm{g} / \mathrm{ml}$ & $10 \mu \mathrm{g} / \mathrm{ml}$ & $1 \mu \mathrm{M}$ & $10 \mu \mathrm{M}$ \\
\hline Acidic FGF-1 & $7.39 \pm 2.19$ & $4.97 \pm 1.51$ & $8.40 \pm 1.72$ & $4.62 \pm 1.86$ \\
E-selectin & $1.14 \pm 0.68$ & $1.42 \pm 1.14$ & $2.28 \pm 0.76$ & $4.60 \pm 3.29$ \\
CD40L & $21.71 \pm 8.03$ & $14.71 \pm 12.14$ & $21.78 \pm 9.63$ & $20.64 \pm 5.12$ \\
\hline
\end{tabular}

II.
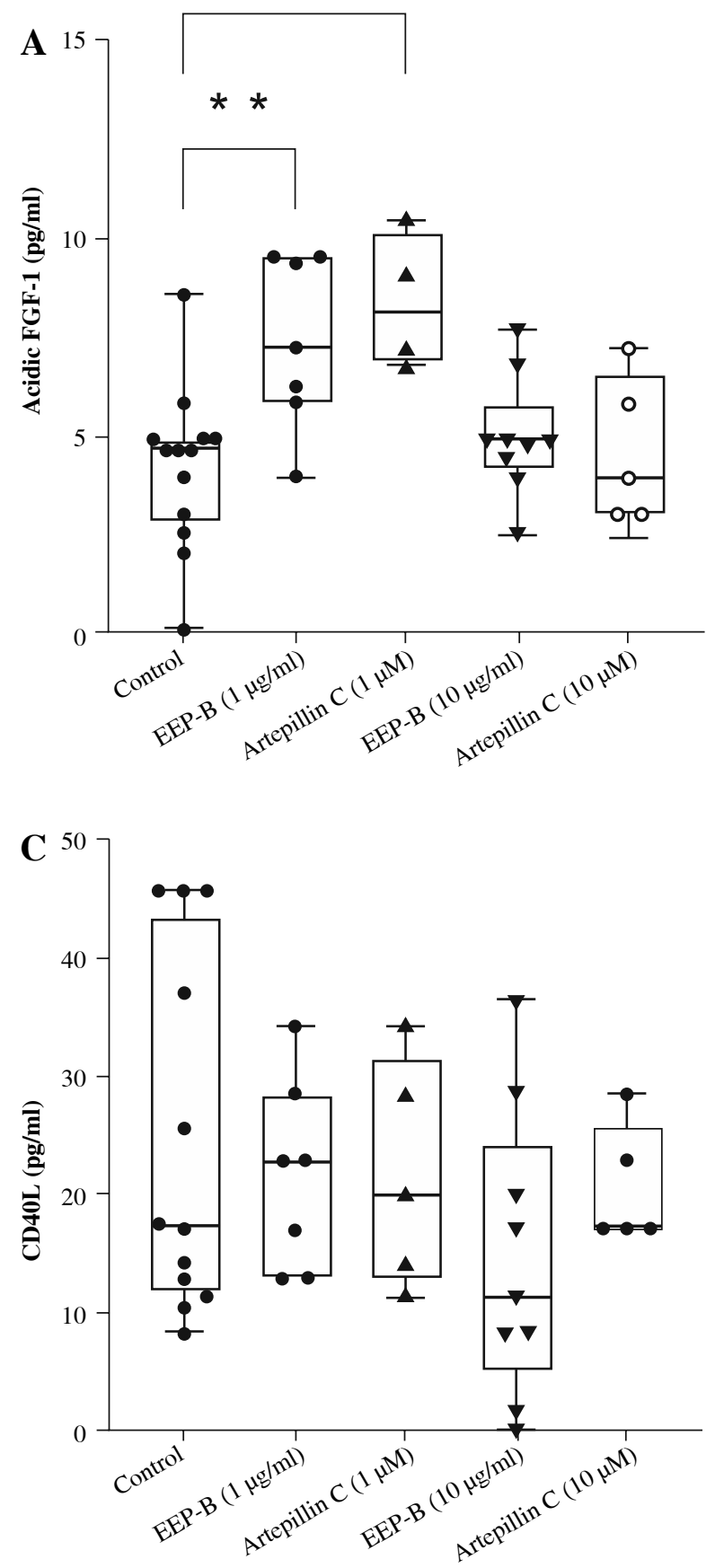

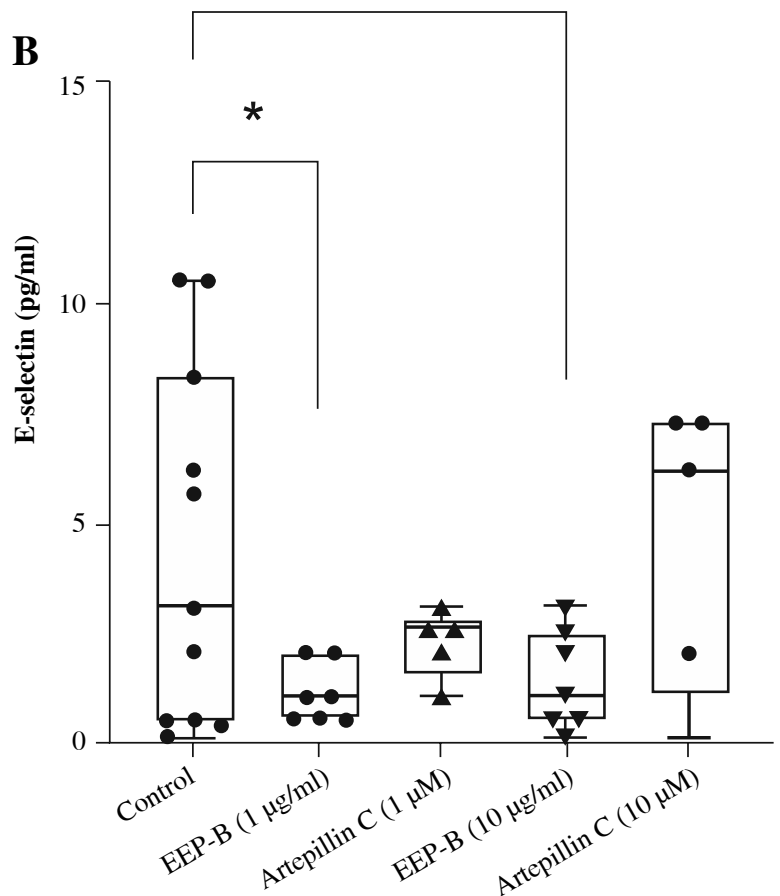

Fig. 3. I. Mean and standard deviation of tested parameters; II. Effect of ethanolic extract of Brazilian green propolis and artepillin C on aFGF-1 (A), E-selectin (B), and CD40L (C) secreted by human gingival fibroblast $(n=8$, $* p<0.05, * * p<0.01)$ 
confirmed by use of artepillin $\mathrm{C}$ of any concentration. The concentration of $\mathrm{SCD} 40 \mathrm{~L}$ released by gingival fibroblasts did not change after using EEP-B and artepillin $\mathrm{C}$ in both concentrations (Fig. 3IIC). It was $24.43 \mathrm{pg} / \mathrm{ml}$ in the control and $21.71 \mathrm{pg} / \mathrm{ml}$ to $14.71 \mathrm{pg} / \mathrm{ml}$ for EEP-B in a dosedependent manner. For artepillin $\mathrm{C}$, it was $21.71 \mathrm{pg} / \mathrm{ml}$ $(1 \mu \mathrm{M})$ and $20.64 \mathrm{pg} / \mathrm{ml}(10 \mu \mathrm{M})$.

Nontoxic effects of EEP-B and artepillin $\mathrm{C}$ were determined at the tested concentrations using trypan blue solution. Cell viability was not less than $93 \%$. We confirmed the viability of HGF-1 cells using MTT assay. The results are presented in Figure 4.

\section{Discussion}

The prevention of gingivitis and periodontitis is based on the removal of bacterial plaque by toothbrushing and using mouthwashes or dental floss. Numerous studies have shown that toothpastes and mouthwashes containing EEP-B have an antibacterial effect [26-28]. Tanasiewicz et al. have shown that the application of toothpaste and gel with $3 \%$ EEP-B efficiently supports the removal of dental plaque and improves the state of marginal periodontium [29]. Pereira et al. conducted a phase II
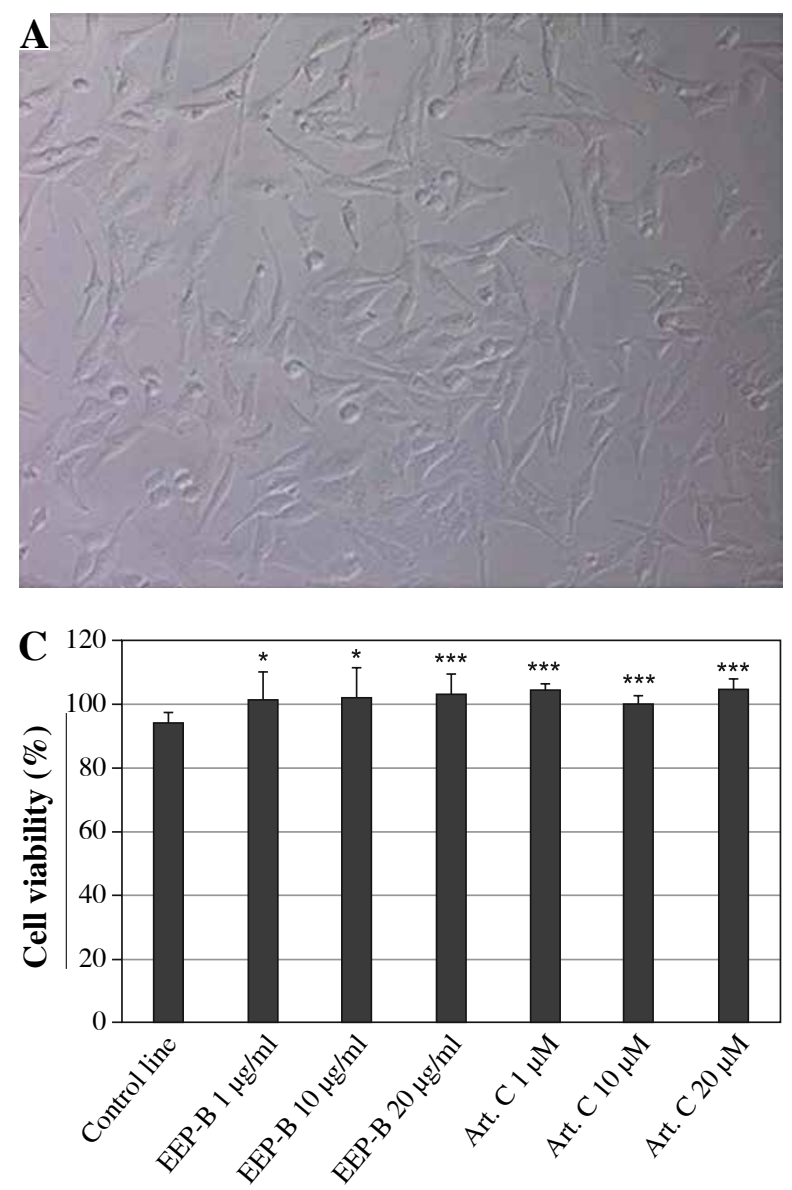

trial study in which they evaluated the effect of 5\% Brazilian green propolis on gingivitis and periodontopathogenic plaque [30]. One and three months after using mouthwash, a significant reduction in plaque index (PI) and gingival index (GI) was observed as compared to the control group.

The role of soluble molecules detected in the supernatant of the HGF-1 has not been clarified yet and little has been reported on acidic FGF-1, E-selectin and CD40L secreted by these cells. In our study, we examined the effect of ethanolic extract of Brazilian green propolis, which is used as an additive to toothpaste, on selected molecules released by human gingival fibroblasts. We compared our results to artepillin $\mathrm{C}$, a component of the Brazilian green propolis. The EEP-B and artepillin $\mathrm{C}$ caused an increase of aFGF-1 concentration. Some studies have shown that aFGF-1 affects cell differentiation and tissue regeneration [31-33]. Our results may suggest that propolis, being a component of toothpastes, affects gingival fibroblasts to secrete increased amounts of aFGF-1 and accelerates wound healing.

E-selectin plays an important role in inflammation. It is produced at the surface of endothelial cells and initiates the migration of polymorphonuclear neutrophils (PMNs) from the gingival vessels to the junctional epithelium [34].

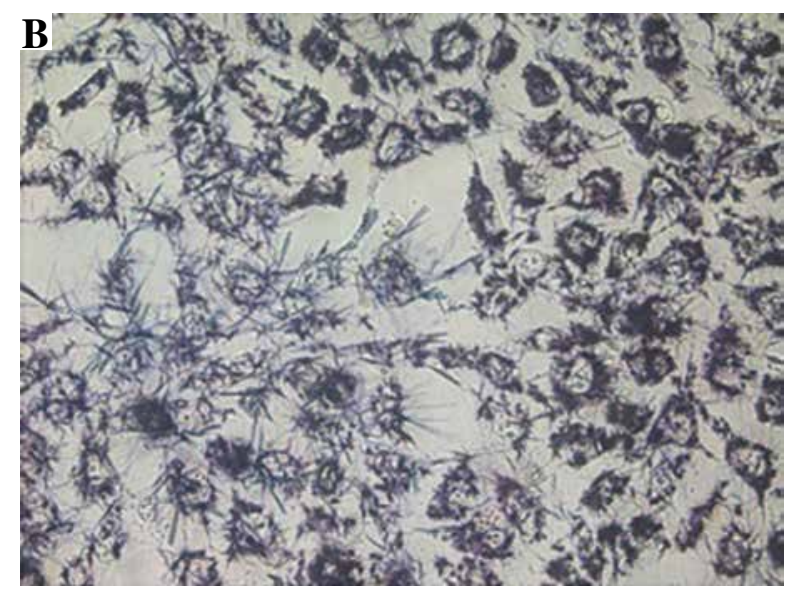

Fig. 4. Cytotoxic activity of EEP-B and artepillin $\mathrm{C}$ on HGF- 1 cells. A) HGF-1 cells (magnification 200×), B) HGF-1 cells incubated with MTT tetrazolium for 4 hours showing formazan crystals (magnification 200x), C) Cell viability (\%). Cytotoxic activity of artepillin $\mathrm{C}$ and Brazilian green propolis on HGF-1 cells. The cells were incubated for 24 hours with artepillin $C$ at the concentrations of 1-20 $\mu \mathrm{M}$ and with Brazilian green propolis at the concentrations of $1-20 \mu \mathrm{g} / \mathrm{ml}$. The cell viability was measured by MTT cytotoxicity assay. The values represent mean $\pm \mathrm{SD}$ of three independent experiments in quadruplicate $(n=12)$; $* p<0.005, * * p<0.01, * * * p<0.001$ 
The concentration of circulatory E-selectin can be used as a marker of endothelium activation. Its expression has also been detected in nonstimulated cells [35]. A number of studies have shown that inflammatory cytokines induce expression of E-selectin in endothelial cells. Leeuwenberg et al. incubated human umbilical vein endothelial cells (HUVEC) with TNF- $\alpha$, IL-1, interferon $\gamma($ IFN- $\gamma$ ) and LPS [36]. The amount of the soluble adhesion molecules E-selectin and intercellular adhesion molecule-1 (ICAM-1) was directly correlated with cell surface expression. Maximal release of E-selectin was observed 6-12 hours after the activation of HUVEC and it decreased below the detection limit 24 hours after the activation. The release of adhesion molecules may reduce the potential adhesiveness of leukocytes by competing with membrane-bound receptors for their ligands. On the other hand, the study of Lo et al. showed that recombinant soluble E-selectin is a neutrophil chemoattractant that activates the integrin CR3 (CD11b/ CD18, Mac-1) [37]. Leukocyte integrin binds to E-selectin, which is essential for the next step, i.e., the movement of PMNs to a connection between endothelial cells and diapedesis. Interestingly, anti-CD18 antibodies block inflammatory movement of PMNs in animals despite the presence of E-selectin [38]. Many studies have shown the anti-inflammatory properties of flavonoids. Takano-Ishikawa et al. showed that luteolin and apigenin have the strongest inhibitory effect among the examined flavonoids on E-selectin expression on HUVEC stimulated by TNF- $\alpha$ [39]. Our results have not confirmed the change in soluble E-selectin concentration after the incubation of HGF-1 with artepillin C. Interestingly, use of EEP-B at $1 \mu \mathrm{g} / \mathrm{ml}$ and $10 \mu \mathrm{g} / \mathrm{ml}$ decreased the concentration of sE-selectin. Perhaps flavonoids contained in propolis act synergistically and enhance its anti-inflammatory properties [40]; however, this requires further research. Toothpastes with the addition of ethanolic extract of Brazilian green propolis have anti-inflammatory properties as a result of the flavonoids contained in it.

CD40L is a costimulatory molecule which is essential for the activation of CD4+ T cells. The CD40-CD40L pathway plays a key role in the functioning of the immune system. Soluble CD40L has been identified as a risk indicator of various cardiovascular diseases [41, 42]. CD40L activates DNA synthesis and mitogenic signaling pathways [43]. Probably not every cell will respond in the same way to CD40L. However, its role in periodontitis is unclear. Chaturvedi et al. investigated the role of SCD40L in the pathogenesis of periodontal disease [16]. They found that the levels of sCD40L in gingival crevicular fluid (GCF) were significantly higher in patients with chronic periodontitis compared to healthy patients. Dongari-Bagtzoglou observed that CD40 interaction with CD40L upregulates IL-6 and IL-8 secretion by gingival fibroblasts [44]. Interesting research results were obtained by the team of Fries et al. in cultured human fibroblasts [45]. Interferon $\gamma$ upregulated the CD40 expression on fibroblasts and shifted them into the G0/G1 phase of the cell cycle. These results suggest that CD40 may facilitate fibroblast proliferation, which is important for tissue repair. Our results, however, did not reveal any significant influence of EEP-B and artepillin C on CD40L.

Periodontal diseases develop as a result of dysregulation of the innate and adaptive immune systems. Understanding the role of molecules produced by gingival fibroblasts would enable the treatment of oral diseases. By analyzing the interactions between gingival fibroblasts and EEP-B, beneficial effects of its use as a component of toothpaste can be noted. Artepillin $\mathrm{C}$ as a single compound has a weaker effect than propolis, which is a mixture of various compounds. Probably flavonoids and phenolic acid derivatives found in propolis have a synergistic effect. However, further research is needed to better understand the immunological mechanisms of EEP-B action in the oral cavity.

\section{Conclusions}

The ethanolic extract of Brazilian green propolis and artepillin $\mathrm{C}$ stimulate human gingival fibroblasts to secrete high levels of acidic FGF-1. The EEP-B causes a decrease of E-selectin secretion by HGF-1 cells. The tested compounds showed no change in the concentration of CD40L secreted by HGF-1. Our results may suggest that ethanolic extract of Brazilian green propolis, due to the content of artepillin C and other various compounds, for example, flavonoids, which act synergistically, may have an anti-inflammatory activity and accelerate the wound healing effects.

The authors declare no conflict of interest.

\section{References}

1. Pihlstrom BL, Michalowicz BS, Johnson NW (2005): Periodontal diseases. Lancet 366: 1809-1820.

2. Gurenlian JR (2007): The role of dental plaque biofilm in oral health. J Dental Hygiene 81: 1-11.

3. Lee IK, Lee MJ, Jang HS (2013): The interrelationship between human gingival fibroblast differentiation and cultivating time. Tissue Eng Regen Med 10: 60-64.

4. Johnson DE, Williams LT (1992): Structural and functional diversity in the FGF receptor multigene family. Adv Cancer Res 60: 1-41.

5. Hui Q, Jin Z, Li X, et al. (2018): FGF family: from drug development to clinical application. Int J Mol Sci 19: 1875.

6. Li X, Wang C, Xiao J, et al. (2016): Fibroblast growth factors, old kids on the new block. Semin Cell Dev Biol 53: 155-167.

7. Wong D, Dorovini-Zis K (1996): Regulation by cytokines and lipopolysaccharide of E-selectin expression by human brain microvessel endothelial cells in primary culture. J Neuropathol Exp Neurol 55: 225-235. 
8. Walz G, Aruffo A, Kolanus W, et al. (1990): Recognition by ELAM-1 of the sialyl-Lex determinant on myeloid and tumor cells. Science 250: 1132-1135.

9. Jubeli E, Moine L, Vergnaud-Gauduchon J, et al. (2012): E-selectin as a target for drug delivery and molecular imaging. J Control Release 158: 194-206.

10. Lobb RR, Chi-Rosso G, Leone DR, et al. (1991): Expression and functional characterization of a soluble form of endothelial-leukocyte adhesion molecule 1. J Immunol 147: 124-129.

11. Bhatti M, Chapman P, Peters M, et al. (1998): Visualising E-selectin in the detection and evaluation of inflammatory bowel disease. Gut 43: 40-47.

12. Kobayashi T, Hashimoto S, Imai K, et al. (2008): Elevation of serum soluble intercellular adhesion molecule-1 (sICAM-1) and sE-selectin levels in bronchial asthma. Clin Exp Immunol 96: 110-115.

13. Grammer AC, Bergman MC, Miura Y, et al. (1995): The CD40 ligand expressed by human B cells costimulates B cell responses. J Immunol 154: 4996-5010.

14. van Kooten C, Banchereau J (2000): CD40-CD40 ligand. J Leukoc Biol 67: 2-17.

15. van Kooten C, Banchereau J (1997): Functions of CD40 on B cells, dendritic cells and other cells. Curr Opin Immunol 9: 330-337.

16. Chaturvedi R, Gupta M, Jain A, et al. (2015): Soluble CD40 ligand: a novel biomarker in the pathogenesis of periodontal disease. Clin Oral Investig 19: 45-52.

17. Bankova VS, de Castro SL, Marcucci MC (2000): Propolis: recent advances in chemistry and plant origin. Apidologie 31: 3-15.

18. Kuropatnicki AK, Szliszka E, Krol W (2013): Historical aspects of propolis research in modern times, evidence-based complement. Altern Med 2013: 964149.

19. Touzani S, Embaslat W, Imtara H, et al. (2019): In vitro evaluation of the potential use of propolis as a multitarget therapeutic product: physicochemical properties, chemical composition, and immunomodulatory, antibacterial, and anticancer properties. Biomed Res Int 2019: 4836378.

20. Przybyłek I, Karpiński TM (2019): Antibacterial properties of propolis. Molecules 24: 2047.

21. Sforcin JM (2016): Biological properties and therapeutic applications of propolis. Phytother Res 30: 894-905.

22. Kumazawa S, Yoneda M, Shibata I, et al. (2003): Direct evidence for the plant origin of Brazilian propolis by the observation of honeybee behavior and phytochemical analysis. Chem Pharm Bull 51: 740-742.

23. Banskota AH, Tezuka Y, Prasain JK, et al. (1998): Chemical constituents of Brazilian propolis and their cytotoxic activities. J Nat Prod 61: 896-900.

24. Szliszka E, Czuba ZP, Domino M, et al. (2009): Ethanolic extract of propolis (EEP) enhances the apoptosis-inducing potential of TRAIL in cancer cells. Molecules 14: 738-754.

25. Kłósek M, Mertas A, Król W, et al. (2016): Tumor necrosis factor-related apoptosis-inducing ligand-induced apoptosis in prostate cancer cells after treatment with xanthohumol - a natural compound present in Humulus lupulus L. Int J Mol Sci 17: 837.

26. Morawiec T, Mertas A, Wojtyczka RD, et al. (2015): The assessment of oral microflora exposed to $3 \%$ ethanolic extract of brazilian green propolis preparation used for hygiene maintenance following minor oral surgeries. Biomed Res Int 2015: 869575.
27. Skaba D, Morawiec T, Tanasiewicz M, et al. (2013): Influence of the toothpaste with brazilian ethanol extract propolis on the oral cavity health. Evid Based Complement Alternat Med 2013: 215391.

28. Niedzielska I, Puszczewicz Z, Mertas A, et al. The influence of ethanolic extract of Brazilian green propolis gel on hygiene and oral microbiota in patients after mandible fractures. Biomed Res Int 2016: 9190814.

29. Tanasiewicz M, Skucha-Nowak M, Dawiec M, et al. (2012): Influence of hygienic preparations with a $3 \%$ content of ethanol extract of Brazilian propolis on the state of the oral cavity. Adv Clin Exp Med 21: 81-92.

30. Pereira EMR, Da Silva JLDC, Silva FF, et al. (2011): Clinical evidence of the efficacy of a mouthwash containing propolis for the control of plaque and gingivitis: a phase II study, evidence-based complement. Altern Med 2011: 750249.

31. Klein-Soyer C, Archipoff G, Beretz A, et al. (1992): Opposing effects of heparin with TGF- $\beta$ or aFGF during repair of a mechanical wound of human endothelium. Influence of cAMP on cell migration. Biol Cell 75: 155-162.

32. Bing M, Da-Sheng C, Zhao-Fan X, et al. (2007): Randomized, multicenter, double-blind, and placebo-controlled trial using topical recombinant human acidic fibroblast growth factor for deep partial-thickness burns and skin graft donor site. Wound Repair Regen 15: 795-799.

33. Dignass AU, Tsunekawa S, Podolsky DK (1994): Fibroblast growth factors modulate intestinal epithelial cell growth and migration. Gastroenterology 106: 1254-1262.

34. Cummings CJ, Sessler CN, Beall LD, et al. (1997): Soluble E-selectin levels in sepsis and critical illness: Correlation with infection and hemodynamic dysfunction. Am J Respir Crit Care Med 156: 431-437.

35. Banquy X, Leclair G, Rabanel JM, et al. (2008): Selectins ligand decorated drug carriers for activated endothelial cell targeting. Bioconjug Chem 19: 2030-2039.

36. Leeuwenberg JF, Smeets EF, Neefjes JJ, et al. (1992): E-selectin and intercellular adhesion molecule-1 are released by activated human endothelial cells in vitro. Immunology 77 : 543-549.

37. Lo SK, Lee S, Ramos RA, et al. Wright, endothelial-leukocyte adhesion molecule 1 stimulates the adhesive activity of leukocyte integrin CR3 (CD11b/CD18, Mac1, CiJ2) on human neutrophils. http://rupress.org/jem/ article-pdf/173/6/1493/490953/1493.pdf.

38. Arfors KE, Lundberg C, Lindbom L, et al. (1987): A monoclonal antibody to the membrane glycoprotein complex CD18 inhibits polymorphonuclear leukocyte accumulation and plasma leakage in vivo. Blood 69: 338-340.

39. Takano-Ishikawa Y, Goto M, Yamaki K (2003): Inhibitory effects of several flavonoids on E-selectin expression on human umbilical vein endothelial cells stimulated by tumor necrosis factor? Phyther Res 17: 1224-1227.

40. Shimizu T, Shibuya N, Narukawa Y, et al. (2018): Synergistic effect of baicalein, wogonin and oroxylin A mixture: multistep inhibition of the NF- $\kappa \mathrm{B}$ signalling pathway contributes to an anti-inflammatory effect of Scutellaria root flavonoids. J Nat Med 72: 181-191.

41. Ferroni P, Guadagni F (2008): Soluble CD40L and its role in essential hypertension: diagnostic and therapeutic implications. Cardiovasc Hematol Disord Drug Targets 8: 194-202.

42. Vishnevetsky D, Kiyanista VA, Gandhi PJ (2004): CD40 ligand: A novel in the fight against cardiovascular disease. Ann Pharmacother 38: 1500-1508. 
43. Hermann A, Schrör K, Weber AA (2002): CD40 ligand (CD40L) does not stimulate proliferation of vascular smooth muscle cells. Eur J Cell Biol 81: 213-221.

44. Dongari-Bagtzoglou AI, Warren WD, Berton MT, et al. (1997): CD40 expression by gingival fibroblasts: Correlation of phenotype with function. Int Immunol 9: 1233-1241.

45. Fries KM, Sempowski GD, Gaspari AA, et al. (1995): CD40 expression by human fibroblasts. Clin Immunol Immunopathol 77: 42-51. 